\title{
The phenomena of power and freedom in the political worldview of A. S. Pushkin
}

\author{
Marina Shirokova ${ }^{1, *}$ \\ ${ }^{1}$ Altai State University, 656049 61a Lenina ave., Barnaul, Russia
}

\begin{abstract}
The article discusses the place and role of A. S. Pushkin in the history of Russian culture and political thought. Such a feature of the Russian picture of the world as "literary-centrism", which is the primacy of the word, confidence in the word. Like other Russian writers, Pushkin's works present a moral ideal, but he does not try to teach something, does not construct an ideal model, but simply shows an ideal in the unity of form and content. Further, the article traces the main stages of the evolution of the great poet's political views: the Lyceum-Petersburg period; the period of the southern exile; the period of exile in Mikhailovsky; and the period of creative maturity in the last decade of his life. The ideological evolution of Pushkin is a transition from liberalism and revolutionism to conservatism and monarchism, combined with the idea of personal freedom. The author concludes that the political worldview of Pushkin organically combined the phenomena of power and freedom. The poet managed to "remove" the dialectical contradiction between them, which later became one of the main problems of Russian literature and philosophy.
\end{abstract}

\section{Introduction}

Any culture, like a person, needs constant focusing of its fundamentals, this is a necessary moment of self-identification - national, state, historical, and so on. Thus, the appeal to the heritage of A. S. Pushkin in the domestic culture will always be relevant.

Almost every generation of Russian writers is going through a period of revolt against Pushkin, which is much like a revolt of children against their parents. By the time of revolt mingled envy and jealousy, which in itself is remarkable, because envy is only alive. One of the characters in Bulgakov's novel "Master and Margarita," Ryukhin, looking at the monument to Pushkin, thought, "Here is an example of real luck ... whatever step he took in life, no matter what happened to him, everything went to his advantage, everything turned to his glory! But what did he do? I do not understand ... Is there anything special about these words: "The storm darkens ..."? I do not understand! .. I was lucky, I was lucky! .. I shot, this White Guard man shot and shot him, and he crushed his hip, and ensured immortality ..." [1, p. 489].

* Corresponding author: mshirokova1@ rambler.ru 


\section{The solar center of our history}

The idea expressed by I. A. Ilyin in the article "Pushkin's Prophetic Vocation" (the article was written on the 100th anniversary of the poet) seems fair. Ilyin argued that Pushkin "was given to us in order to create the solar centre of our history" [2, p. 353]. It is noteworthy that this was said not about a state official or, for example, about a religious figure, but about a literary man. V. S. Nepomnyaschiy writes in this connection, "Such a judgment is possible only in Russia and applied only to it, this is a Russian judgment; for one who wants to understand Russia, this alone should cause close attention, even if Ilyin exaggerated in this case. But he did not exaggerate. He formulated an unaccountable public attitude towards Pushkin" [3, p. 407]. Ilyin's formula puts the question in context to help clarify the nature of the links between the Pushkin phenomenon and the phenomenon of Russian spiritual culture.

Among other things, Ilyin's judgment reflects such a feature of the Russian picture of the world as "literary-centrism," which is the primacy of the word, confidence in the word. The word in all areas of our culture and civilization means, perhaps, more than a deed. "The poet's words are already the essence of his business", said Pushkin. Our literature in many ways creates, constructs reality, including political reality. Most, if not all, political movements in Russia have literary sources, and even the founders are the literary heroes, such as, for example, Turgenevsky's Bazarov.

On this account, however, there is an opinion expressed by many authors, and, first of all, by N.A. Berdyaev in the book "The Origins and Meaning of Russian Communism". According to the philosopher, "Russian thought ... was in the 19th century internally free and bold ... outwardly constrained and often persecuted. The impossibility under the political conditions of direct social affairs led to the fact that all activity turned into literature ..., where all questions were raised and solved very radically. An unlimited social daydreaming developed, not related to reality" [4].

On the other hand, it is precisely Pushkin who (unlike the materialists such as V. G. Belinsky, N. G. Chernyshevsky, D. I. Pisarev, the populists of the 70s, as well as the antimaterialists - N. V. Gogol, L. N. Tolstoy, F. M. Dostoevsky, and others) practically did not suffer from "social dreaminess". Berdyaev, like many others, writes that Pushkin cannot be attributed to intellectuals. However, the Russian literature after him "becomes learning, it searches for the truth and teaches the realization of the truth". "Russian thinkers ... always looked for not so much a perfect culture, perfect products of creativity, but a perfect life, a perfect truth of life" [4]. Berdyaev also refers Pushkin to the creators of a perfect culture and calls him the only representative of the Russian Renaissance. This conclusion was made by the philosopher on the grounds that Pushkin, in several written sources that came down to us, repeats, "The goal of art is the ideal, not moral teaching" [5, v. 10, p. 141]. It is often believed (as Berdyaev also believed) that aestheticism is meant, an aesthetic ideal is opposed to the moral ideal ("moralizing"). But still, another point of view looks more reasonable: the poet contrasts the ideal and the reality, the proper and the real. And in this respect, Pushkin is no different from other Russian writers. He has a moral ideal, but he does not try to teach something, does not construct an ideal model. He simply shows this ideal in the unity of form and content in a way that no one else has ever succeeded. Only in Pushkin's work is the presence of the ideal so familiar that we stop noticing it. As G. P. Fedotov notes, "In this death of habitual perfection is the main reason for the coldness of Pushkin we often have" [6, p. 365].

According to V. S. Nepomnyaschiy, the originality of the genius of Pushkin and his place in the national culture is the same outstanding as the peculiarity of Russian spirituality among other types of spirituality. "Recall, further, that universality, openness, and all-humanity, which Dostoevsky considered to be the unique, inimitable property of 
Pushkin, but at the same time of the Russian spiritual stock in general. Or the generally accepted indefinability of the "specificity" and "originality" of Pushkin's genius. Doesn't it "duplicate" a similar feature of Russian spirituality? It is known that the Russian warehouse is often perceived as vague and amorphous. And so are the views that Pushkin as a writer has no "personality" as well" [3, p. 406].

The Russian culture is often blamed for the fact that it contains an extremely large amount of borrowing, and that if you select from it all kinds, all the genres of art were borrowed from France, Italy, Germany, and also from the people of the East, then practically there's nothing really Russian. And if we exclude from the number of Russian writers, artists, composers, and so on, all persons with foreign roots - Tatars, Poles, Germans, Dutch, and others by origin - it turns out that there is no truly Russian in our culture! Yes, and Pushkin, as you know, his black grandfather, Hannibal, "was bought for a bottle of rum and fell into the hands of a skipper". But it is obvious that this particular feature forms the Russian culture as universal and, at the same time, unique. All borrowings from other cultures, and all people from other nations left their marks in history precisely as the Russians. And it was precisely the Russian culture of the 19th century that acquired a world-wide significance, unlike, say, American, which also absorbed elements of very different cultures from around the world.

In the Russian culture there are many borrowings, and there are also a lot of them in Pushkin's works. It is characterized by the habit of absolutely shamelessly using "alien" material, in which no one, including Shakespeare, compares with our poet. For example, Russian novels by other authors, French comedies, German "anecdote", and much more became the sources for "The Stories of Belkin". At the same time, Pushkin himself said about the work of the fictional author, and in fact, about his own: "It's necessary to write a story like this: simply, briefly and clearly!" [7, p. 234]. In reflections on "Boris Godunov", he notes that he could compile a preface, where he would explain to everyone "how to write" tragedies, but simply did not want a "scandal". Or another case: Pushkin says about the novel of his contemporary Zagoskin that the author wrote everything wrong, that "in fact" everything was wrong!

In other words, they confuse something, but he puts everything in its place. He uses other people's texts, plots, images in the same way as the composer uses the same seven notes as the others. The point is that he succeeds in creating harmony, while others do not.

Let us return to the idea that Pushkin created the spiritual centre of our history. Indeed, in his work he succeeded in combining the history of pre-Peter and post-Peter the Great Russia (Herzen said that Russia responded to the reform of Peter by the appearance of Pushkin), to connect Slavophilism and Westernism, which Dostoevsky mentioned in his famous speech at the opening of the monument to the poet. In addition, Pushkin completely organically combined Russian folk culture with classical, elite culture.

\section{Political views}

With regard to his political views, it is worth noting that Pushkin succeeded, at least "for a moment," using the words of Berdyaev, to show in unity the ideas of power and freedom. These are two phenomena, two dialectical opposites, the correlation of which was one of the main problems in the history of Russian political thought, starting with the "Word of Law and Grace" by the Kiev Metropolitan Hilarion. Berdyaev, in fact, notes, "It seemed as if for an instant that what was always separated from us, the ideology of the empire and the ideology of the intelligentsia connected. "He wrote revolutionary poems, and he was the poet of the Russian great power" [4]. G. P. Fedotov called Pushkin "a singer of the empire and freedom". 
Both components - power and freedom - always attracted the attention of Pushkin. Despite the fact that he made a noticeable ideological-political evolution in his short life, moving (of course, roughly and schematically) from a liberal person (and even a liberal revolutionary) and becoming a conservative, as well as turning from Europeanism to the national beginning, which was called then the "nationality".

In the early Lyceum-Petersburg period of life, until 1820, before the southern exile, Pushkin's first political mentality, like that of the entire generation of young people, was based on a combination of patriotic upsurge associated with the victory over Napoleon with the so-called "freedom-loving dreams". The latter boiled down to the liberation of the peasants, to the idea of a constitutional monarchy, to domination over the kings of the "eternal law" ("Liberty", 1819). Although, the concept of "eternal law" is already much more capacious in meaning than the simple constitutionalism. After all, no positive law, no code of laws cannot be eternal.

In the first exile, in Kishinev and Odessa, Pushkin met with the members of the "Southern Society" of the Decembrists, and his political views were briefly radicalized. Moral indignation against the government also played its role. But already in this period there were signs of a future conservative outlook, in particular, disappointment in the possibility of successful propaganda of freedom, as it was expressed in the famous poem "Freedom, Sower of the Desert" (1823), transcribing the Gospel parable. In a letter to A. I. Turgenev, sending him an ode to the death of Napoleon, Pushkin writes, "However, this is my last liberal nonsense, I repented and wrote the other day the imitation of the fable of a moderate Democrat I. X.” [5, v. 10, p. 75].

During the second exile, in the Mikhailovsky, from 1824 to 1826, despite growing irritation against police surveillance and plans to flee abroad, Pushkin continues to move toward conservatism. Writing the tragedy "Boris Godunov" and studying the history of the Troubles lead him to the conviction that the monarchy was the foundation of the political life of Russia. The result of his development was reflected in Pushkin's judgments about the December uprising and its suppression, and, in this connection, about the revolution in general. "I never liked rebellion and revolution, this is true; but I was in touch with almost everyone and in correspondence with many of the conspirators" [5, v. 10, p. 211].

Finally, the last decade of the poet's life is a period of spiritual and political maturity. "With the accession of Nicholas I, the social status of Pushkin ... was changing; and his attitude to the personality of the new king was from the very beginning to the end of the poet's life, despite many disappointments, resentments and irritations, completely different than to the personality of Alexander. The king ... first ... granted him freedom, promised to get rid of petty quibbles of censorship, taking upon himself the role of his "only censor"; in fact, under the guardianship of Benkendorf, not only literary activities, but also the poet's personal life remained under police supervision until his death" [8, p. 407].

However, Pushkin had already been formed since 1826. As S. L. Frank wrote, he was deeply state-owned ... wise and sober, combining fundamental conservatism with principles of respect for individual freedom and cultural improvement. "This was due, above all, to his constant interest in Russia's foreign policy. In this regard, Pushkin represents an absolute unique example in the history of Russian political thought, if compared to independent and opposition-minded Russian writers of the 19th century. Pushkin was one of the few people who remained in this sense true to the ideals of his first youth - the ideals of a generation that had survived the patriotic excitement of 1812-1815 at the beginning of life. By the end of the $1820 \mathrm{~s}$ and in the $1830 \mathrm{~s}$, most of Pushkin's peers lost this state-patriotic consciousness. It happened partly due to the instinctive sense of Russia's unshakable state strength that dominated Russian minds throughout the 19th century, partly due to the sentimental cosmopolitanism and statelessness, which was peculiar to the Russian intelligentsia already then [8, p. 409]. Already in 1832, Pushkin expressed himself in 
relation to his not at all radical friend Vyazemsky, that he belonged to "embittered people who did not love Russia," and noted the sore spot of Russian liberalism, mentioning people who "stand in opposition not to the government, but to Russia."

Pushkin's political conviction explains his well-known attitude to the Polish uprising of 1831 and to the attempt of European intervention in Russian-Polish affairs. By the way, this attitude caused criticism of such friends of Pushkin as Vyazemsky and Turgenev, who believed that a truly freedom-loving artist had to side with the Poles, the people fighting for independence. Pushkin also wrote the famous ode to "Slanderers of Russia", in which he glorified the power of the empire.

For a poet, the Russian statehood is a continuous overcoming of the onset of chaos by the beginning of reason and will. This is the meaning of the empire for Pushkin. Thus, he anticipated the idea of the 19th century Russian conservatives that the empire was a world for its citizens.

Similarly, in his earlier poem "The Prisoner of the Caucasus", Pushkin does not side with the freedom-loving Highlanders, as Byron or Walter Scott would have done. On the contrary, he makes the Russian a prisoner, and when he escapes from captivity, for him the Russian bayonets glittering in the fog become a symbol of freedom.

Another motive of Pushkin's conservatism is respect for the historical past, for traditions. And this motive is also closely connected with freedom, since love of "for the native ashes" and "for fatherly coffins" "is based on the self-stability of man for centuries, a pledge of his greatness". "From this consciousness follows the well-known demand for respect for the old clan nobility, as the bearer of the cultural and historical succession of the country" [8, p. 413].

Generally, Pushkin, of course, was not a democrat in the political sense of the word, he was rather a supporter of the aristocracy. He wanted freedom for the people, but not the power of the people. In this regard, he expressed strongly on post-revolutionary France, of the United States, reading the book of Tocqueville's "Democracy in America". Traditionalism and the poet's aristocracy reinforce him in the thought of denying the revolution: "God forbid, see a Russian revolt, senseless and merciless!" ("The Captain's Daughter", 1836). He expresses the same idea in a positive form, "The best and most solid changes are those that come from a single moral improvement, without violent political upheavals, terrible for humanity" [5, v. 7, p. 291-292].

Nevertheless, the words "freedom, liberty, will", as well as the adjective "free", are more often found in Pushkin's poetry. The poet finds infinitely diverse embodiments of freedom. According to B. P. Vysheslavtsev, the author of the book "The Eternal in Russian Philosophy", Pushkin expressed "all the significance of freedom, all its degrees": from elemental, natural to civil and political, and further to higher, spiritual freedom, "freedom of prophetic speech, not afraid of a kingdom nor priesthood" [9]. "I do not know a freer mind in Russia than Pushkin," the philosopher argued.

\section{Conclusion}

At the same time, the poet valued different manifestations of freedom to varying degrees. In the most vivid form, this position is expressed in the famous poem of 1836, "I don't value loud rights dearly ..." Pushkin does not demand the right to active participation in political life and civil liberties, such as freedom of the press (even on the contrary, he was convinced of the need for censorship to preserve public morality, and he had extensive arguments in this regard in the article "Thoughts on the Road"). It requires the spiritual independence of the individual, as well as the expanse of spiritual life and creativity. No accident that the poet called his novel "Eugene Onegin" as being a "free romance". Thus, it appears that P. 
A. Vyazemsky was right. He defined the political direction of mature Pushkin as "free conservatism".

\section{References}

1. M. A. Bulgakov, White Guard: Theatrical novel. The Master and Margarita (Fiction Literature Leningrad Branch, Leningrad, 1978)

2. I. A. Ilyin, Pushkin in Russian philosophical criticism: Late XIX - first half of the XX century (Kniga, Moscow, 1990)

3. V. S. Nepomniachtchi, Pushkin. Selected Works of the 1960s - 1990s : in 2 volumes. Volume 2: Pushkin. Russian world view (Moscow textbooks, Moscow, 2001)

4. N. A. Berdyaev, The origins and meaning of Russian communism (http://www.vehi.net/berdyaev/istoki/00.html, 1990)

5. A. S. Pushkin, Complete works in 10 volumes (Publishing House of the Academy of Sciences of the USSR, Moscow, 1958)

6. G. P. Fedotov, Pushkin in Russian philosophical criticism (Kniga, Moscow, 1990)

7. Russian archive: Historical and Literary Collection, 3 (1902)

8. S. L. Frank, Pushkin in Russian philosophical criticism (Book, Moscow, 1990)

9. B. P. Vysheslavtsev, The eternal in Russian philosophy (Chekhov Publishing House, New York, 1955) 